\title{
土木界における岩艋力学の動向*
}

畑野正**

\section{A Recent Trend of Rock Mechanics in the Field of Civil Engineering}

by

\author{
Tadashi Hatano
}

(Central Research Institute of Electric Power Industry, Tokyo)

In the field of civil engineering in Japan particular attention has hitherto been paid to rock mechanics mainly in relation to the problems on dam foundation.

In 1960, the first study group on rock mechanics was organized, and its 1st symposium was held in 1962 at which the engineers concerned, including tunnel and soil engineers attended. The 2nd symposium was held in 1963 under the auspices of the above mentioned study group and was reorganized into a "Committee for Rock Mechanics of the Japan Society of Civil Engineering," with about 50 members concerned. This committee is currently divided into five divisions where valuable and zealous discussions and presentation of study achievements are made once a month.

This paper explains briefly the methods actually used and the recent representative studies concerning rock mechanics in the field of civil engineering in Japan, which covers extremely diversified problems such as on combination of applied geology with rock mechanics, on various observations in situ and their interpretation, on analytical and model studies, on foundation treatment of real structures, on water movement in fissured rocks, and so on.

(Received Jan. 11, 1965)

\section{1 前 言}

ダムやトンネル等の土木構造物に関する岩盤力学の 問題は，乙れらの構造物を取り扱う場合に必然的に生 じてくる重要な課題であるが，土木の分野におけるそ の発展の経過を顧みると，つい近年までのゆるやかな 発展段階と最近の非常に強い関心を集めている段階の 二者に区分できるように思われる，第 1 の段階では， 弾性論などを主要な手段として，いわば観念的な机上 の理論が多かったのであるが，多くの土木構造物の研 究がそうであるように, 戦後の計測技術の発展に伴い, 実物に関する測定を実施して，現実に近い状況を把握 し，乙れから従来の単なる観念論を根本から見直して， 新しい理論を組み立てるという態度が, 岩盤力学につ いても, 要求されたととが第 2 の発展段階を促進した 一つの要因であろう。またダムについていえば，急速 な国内の開発に伴って，やや困難な岩盤地帯において もダム建設を行なわねばならない状況から，堤体より もむしろ岩盤を通じて構造物の安定性を確保すること が重要な課題となったととも，その要因の一つであろ う。さらにまたフランスにおけるマルパッセダムの崩 壊，イタリアのバイヨントダム地点の地すべりによる 惨事等も岩盤力学を重要視しなければならないという

* 原稿受理 昭和40年 1 月11日

** 電力中央研究所 東京都北多摩郡狛江町
警鐘となった，最近の土木界における研究として，組 織的には，1960年まずダム技術者の間でダム基礎の岩 盤力学についての情報交換の研究グループが結成され た。これがしだいに拡大され，1962年にはトンネル技 術者, 土質工学者を含めて, 岩盤研究会の名の下にシ ンポシウムか開かれた。との研究会は1963年土木学会 の中の岩艋力学委員会として約 50 名のメンバーで再編 成され，第 2 回のシンポジウムが開かれた。

岩盤力学委員会は今のところ五つの分科会に分かれ, 特長ある課題どとに月々討議や研究紹介が行なわれて いる，岩盤力学には力学と地質学との結合の問題，岩 盤の現地テストによる実状把握の問題，解析的または 模型実験的研究の問題, 実際構造物の基礎好理法の問 題, あるいは浸透流の問題等, 多方面にわたる問題の 採り上げ方が考えられる，以下主要な課題別に現在土 木工学の分野で行なわれている岩盤力学の手法ならび に特長ある最近の研究等について紹介しよう.

\section{2 地質学との関連}

応用地質学と力学との融合, これは岩盤力学上の一 つの重要な課題である. 土木の分野でのとの問題はな おきわめて不充分な状態にあり，特に力を注がねばな らない面である，岩盤力学に関係ある重要な地質的特 質としては，まず，岩盤の均一性を左右する分離面の 存在があげられる。岩盤の中に発達する節理や破砕帯 
などの分離面は, その力学的な性質に重大な変化を与 える原因となっているので，その地質的特徴，分布状 態を解明するてとが必要である。乙のほか岩石そのも のの性質として風化程度, 強度などが重要なものであ る。乙れらの地質的特質は岩艋力学として応用できる ような形に表現するてとが必要である。現在岩艋内の 分離面を表現するため, 通常シュミット網またはウル フ網という特殊な球面投影のグラフを用いて，統計的 方法によってその集中方位を求めるてとが行なわれて いる，乙れは，元来，岩石学にわいて変成岩類の研究 に用いていた方法を応用したものである。乙の統計値 を求めるためには，現地において地表や武掘横坑内で， たくさんの分離面を適当にサンプリングして測定する ことが必要である。Fig. 1 は，シュミット網を用い て作成した，あるダムサイトにおける分離面の密度分 布図で，黒く塗った部分によって卓越した方位が示さ れている。アーチダムの基礎の調查などでは，ての図 にスラストの方向を記入すると，乙れと分離面の方向 との関係を恰討するとともできる.

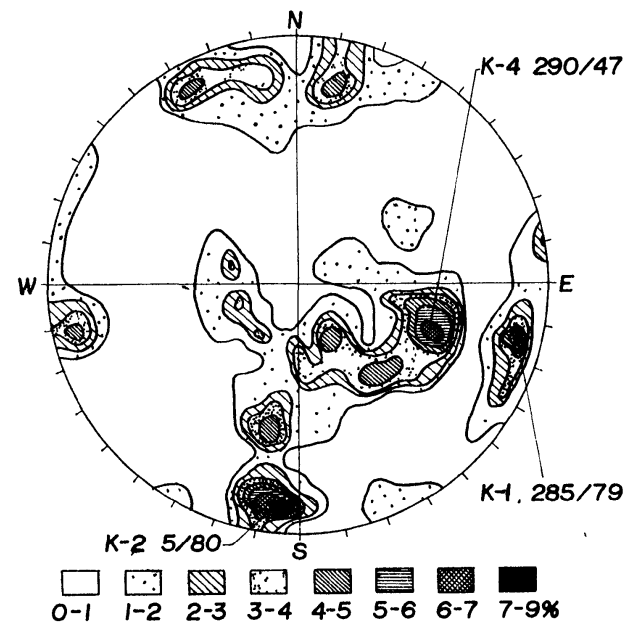

Fig. 1. Density diagram of Schmidt net.

また岩石斜面の安定度の検討にも使用できる。次に 岩艋の強度を試験する場合の地質学上の問題点として, 次のような点が考えられる。

（1）分離面の性質：節理，破碎带の方向および分布， 間隙内の充てん物質，面の平面性など

（2）岩石そのものの性質：風化程度，珠繀強度，弾 性係数など

（1）については試験体内に発達している分離面の走 向, 傾斜を測定することはもちろんであるが，多くの 場合, 乙れらの面はある限られた範囲にのみ分布して いるので，それらの状況を図で示すのがよい，Fig. 2 はある噴出岩よりなる試験体の節理をその展開図に示

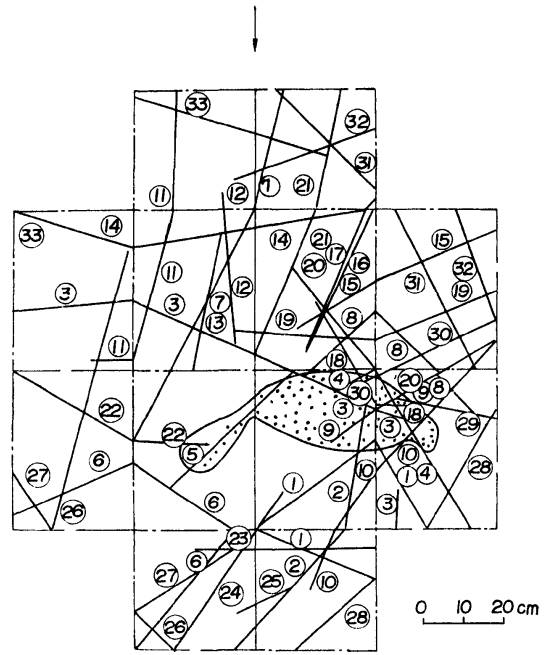

Fig. 2. Distribution of joints in the specimen.

したもので，側面では長さの短かい節理も上面では長 くのびているてとが明りょうに認められる。最近では， このような四から地質的特質の一つとして, 面の平均 間隔や試験体内に含まれる節理の総面積を計算によっ て求めることも行なわれている。乙れらによって岩塊 としての強度を, 岩石そのものの強度と節理との組み 合わせにより推定しようと努力されているのである。 充てん物質は粘土, シル卜，ある場合には，熱水作業 によって二次的に生成された物質のとともあり，乙れ らの状態を土質力学または地質学での分類に従って記 載している，面の平面性や平滑度などもまた岩盤の力 学的性質になんらかの影響を与えるものと考光られる が，乙れらについては，現状では数值的に表現するて とがむずかしいので, 記載的な用語によって説明して いる。たと兊ば，平面性については平面とか曲面とか， また平滑度についてはなめらかとかあらさとかの用語 を用いている。

（2）の岩石そのものの性質のうち，压縮強度，弾性 係数などの物理的性質は，現地の試験体付近から採取 したテストピースによる測定值をもって表わしている。

風化程度については，乙れを表現する方法が確立さ れていないが，肉腿観察または八ンマーの打診などに よって，風化してないものから完全に風化したものま でを 6 等級に分類して記載することが行なわれている. 以上の上うに，複椎な地質現象を力学に結びつけるた めの試みは徐々にではあるが行なわれている。しかし なおみちは迼い状態である。乙の問題の発展は応用地 質学に習熟した力学者，力学を充分に駆使できる危用 地質学者の養成など，力学と地質学との結合の、トに立 脚しなければならない重要な問題である。

\section{3 現地 テスト}


現地岩盤そのものの変形とか，強度などの特性を調 べるために，現地テストが盛んに行なわれている。乙 れらの特性は，基礎岩盤の変形を加味した構造物の設 計を行なうとか，基礎岩盤の安定を検討するとかの目 的で調査されるものである。変形試験として最も一般 的に用いられるのはジャッキ法である．Fig. 3 は剛 性の大きな載荷板を介して岩盤に一様変位を与える方 法で，直径数 $10 \mathrm{~cm}$ の載荷板に 50 ～200t 程度の圧力を

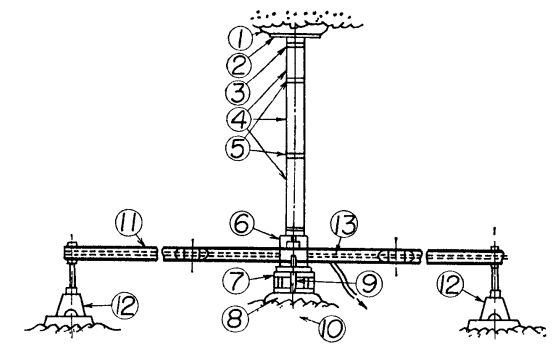
(1) Upper facing
(8) Facing
(2) Steel plate
(9) Dial gauge
(3) Steel head
(10) Rock foundation
(4) Steel column
(11) Reference beam
(5) Joint
(12) Supports of reference beam
(6) Oil jack
(13) Pipe for oil préssure
(7) Steel plate

Fig. 3. Jack test (Constant deformation).

油圧ジャッキで加え，不動点からダイヤルゲージ等を 使用して載荷板の沈下を測定し，荷重一変位曲線を求 めている. Fig. 4 は油封入のダイヤフラムを介して 一定応力を与える方法である，80〜 $120 \mathrm{~cm}$ の直径のダ イヤフラムに 200 800t 程度の荷重を与えてダイヤル ゲージ等でダイヤフラム中心部の変位を測定し荷重一

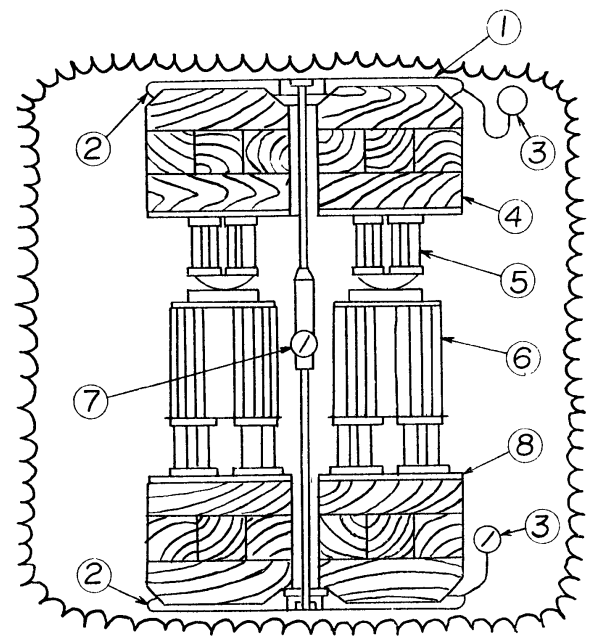
(1) Facing
(5) I beam
(2) Diaphragm of oll
(6) Jack
(3) Pressure gauge
(7) Dial gauge
(4) Timber transmitter
(8) Steel plate

Fig. 4. Jack test (Constant pressure).
変位曲線を求めている。乙れらの曲線のこう配により 弾性係数を弾性計算から推定したり，永久変形を知っ たりする。乙の曲線の性質はきわめて複雑で実際設計 に使用すべき弾性係数，変形係数の決定はその目的に 応じて相当複雑なものがある. 静的な変形試験には乙 のほかに水室法がある．Fig. 5 のように円筒形水室 を作り, 内部水圧を加えて半径方向の延びをカールソ

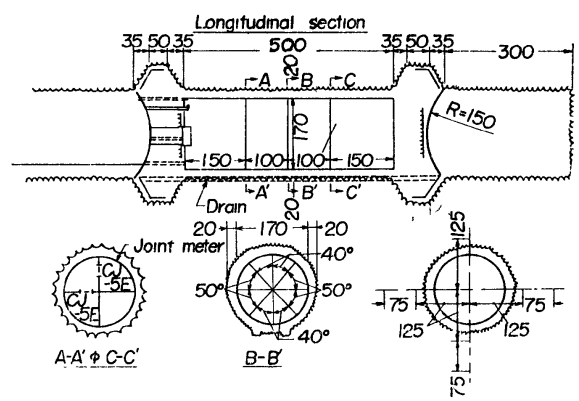

Fig. 5. Chamber test.

ン継目計で測定している，前と同様荷重一変位曲線を 求めて岩盤の変形特性を求めるが，載荷面積が大きく， 岩盤の局所的な部分の影響の少ない結果が得られるの が特長であるが,. 実験規模がジャッキ法に比べて相当 大きくなる，以上は局所的なテストであって，地山全 般の性質を調べるには相当の数が必要である，そこで 弾性波試験によって伝播速度を測定し，てれから地表 はもちろん，山の相当の深さまでの全般的な性質を把 握するてとが行なわれている. Fig. 6〜8 に示すよう に横坑内の屈折波法によるもの, 横坑内の平均速度法 によるもの，小間隔の穴でとの直接波法によるもの等， いろいろな測定法が使用されている．特に直接波法は 狭い範囲の精密な測定に適しており，掘削による岩盤 のゆるみの範囲とか，グラウト前後の速度変化からグ ラウト効果の推定にも使用されている，測定された速 度から弾性論に従って一応弾性係数を計算することが できるが，ての值はジャッキ法および水室法によって 求めた值と同一岩盤に対し，おおよそ10：2：1程度

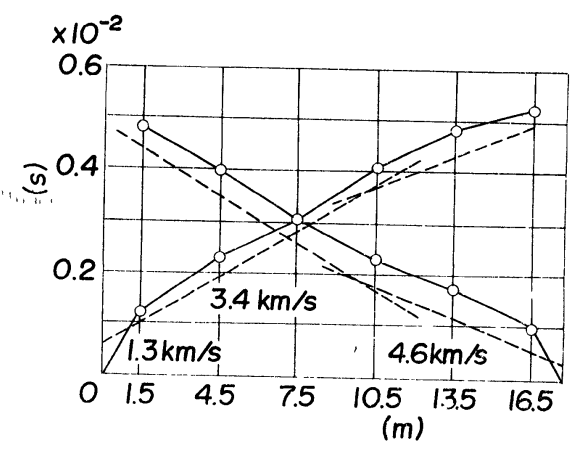

Fig. 6. Refracted wave method. 


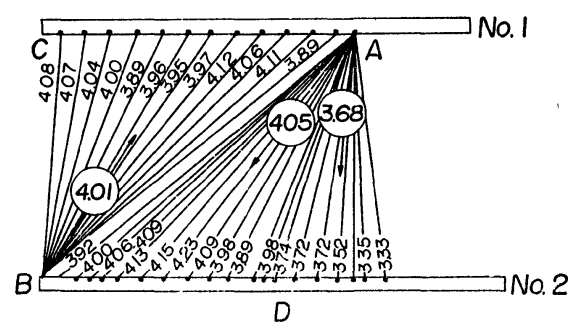

Fig. 7. Mean velocity method.

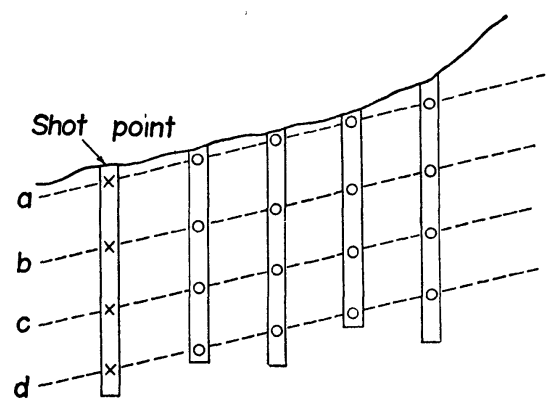

Fig. 8. Direct wave method.

の関係にあるといわれている。弾性係数として設計に 実際に使用するには，その目的に応じて充分の注意の 下汒適当な換算が必要になってくる。

地山としての強度を知るためには，現地岩盤強度試 験が行なわれている，岩盤そのもの，岩盤の分離面， 断層粘土，またはコンクリートと岩盤の接着面等につ いて, クーロンのせん断摩擦強度の式 $\tau=c+\sigma \tan \phi$ を 求めるのが一般で，Fig. 9 はその試験方式の一例を 示すものである，岩質や岩盤のめの間隔等から試験ブ
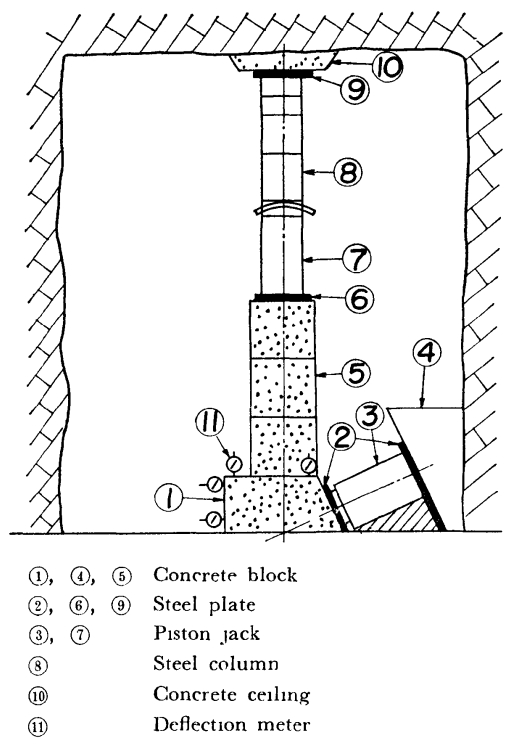

Fig. 9. Shearing test.

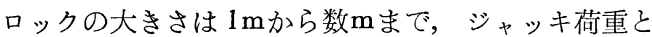
して数 $100 \mathrm{t}$ から数 $1000 \mathrm{t}$ までの荷重が使用される. このほか，3 軸圧縮試験や引き报き試験を行なった例 もある。この強度試験は実験規模としてきわめて大き いものであるから，あまり多数は行なわれていないが， 試験ブロック内の応力の分布ならびにその伝播の状況， ヷロック全体としての破噮に至る前の局部的破壊の進 行等，岩盤破壊論の基本となる問題がしだいに観察解 明されつつある状況である。

\section{4 基礎処理の実例}

各種の困難な岩盤基礎の実際の条件を改良して設䛅 施工した例を，ダムの場合について紹介しよう。

\section{4 ・1 川俣ダム（コンクリートアーチ高さ $120 \mathrm{~m}$ ) の 基礎処理}

川俣ダム地点は堅硬な石英粗面岩質溶結凝灰岩から なる急峻なU字形の谷を作っているが，Fig. 10 亿示 すように断粕，シ一公等が非常に発達しており，左岸 ではアーチダムの基礎としてかなり問題を含んでいる。

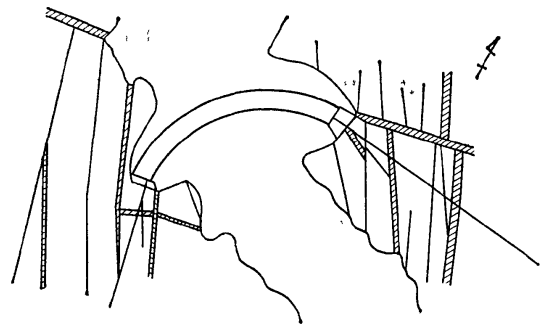

Fig. 10. Kawamata dam (Faults).

このような地質状態にもかかわらず，他にダム地点 がないとと，コンクリート用骨材の採取条件等により， 大規模な地質改良工事を行なってもアーチダムが経済 的であると判断されたため, 岩盤の力学的性質, 種々 の改良案について研究が行なわれ，次の改良工事が行 なわれて現在一部湛水中である。

4・1・1 Transmitting wall アーチバットメ ント近傍に作用するせん断応力を減ずるためにアーチ

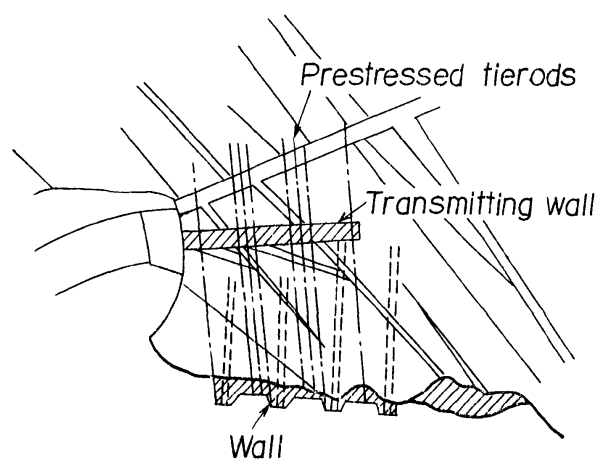

Fig. 11. Kawams.ta dam (Foundation treatment). 
スラストを奥に追い込み，結果として岩盤のすべり破 壊面を山側に追い込むととを目的とする杭状構造の Transmitting wall か計算および模型実験により研究 され，乙の構造物を入れた範囲が一体化されるととを 確かめ着工された。

4.1.2 Prestressed tie-rods 上記 Transmitting wall の掘削施工時に岩盤をゆるめるととを補 ない，さらに岩盤の一体化を図るため，左岸プレスト レス量24000tの Prestressed tie-rods を埋設した。

(Fig. 11).

\section{2 鳴子ダム（コンクリートアーチ高さ $\$ 5 \mathrm{~m}$ ) の 基礎処理}

鳴子ダム地点は花コウ閃縁岩および石英粗面岩から なり，その境界は破碎帯である。乙の地点ではアーチ

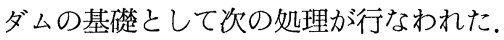

$\mathbf{4 \cdot 2 \cdot 1}$ 河床プラグ 左岸側河床にある厚さ約 $1 \mathrm{~m}$ の上下流传通る傾斜 $50 \sim 60^{\circ}$ の压研部に対し，止水の

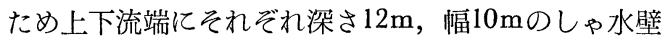
を作って漏水を防ぎ，乙れらの中間に深さ $6 \sim 8 \mathrm{~m}$ ， 幅 6 〜 10mのくさび状のプラグを施工した.

$\mathbf{4 \cdot 2 \cdot 2}$ 二また基礎工 右岸上部の高さ $25 \mathrm{~m}$ 区間 および左岸上部の高さ $21.5 \mathrm{~m}$ の区間では, 風化の進ん だ圧砕された岩盤に，厚さ $20 \sim 30 \mathrm{~cm}$ の粘土㜿がはい っている。しかし，アーチアバットメントから20〜35 mはいった位置では良好な岩盤となるので，アーチス ラストをての部分に伝達させ, あわせてしゃ水壁を兼 ねる2列のコンクリート壁（二また基礎）を施工した。 (Fig. 12).

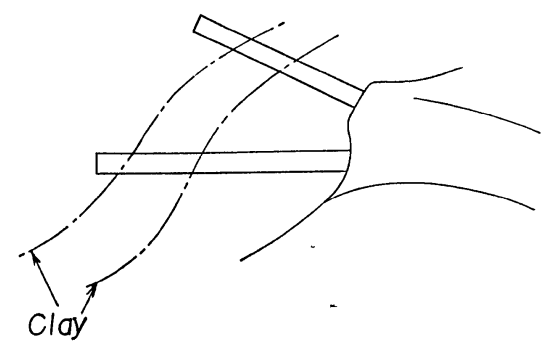

Fig. 12. Naruko dam (Foundation treatment).

4.2.3 右岸のコンクリート置換 右岸の二また 基礎の下部の粘土屏, および厚さ約 $2 \mathrm{~m}$ の貫入石英粗 面岩が俨化し，粘土化している部分を高さ $15 \mathrm{~m}$ ，長さ $15 \mathrm{~m}$ にわたり掘削除去し，コンクリートで置き換えて 基礎岩盤の変形，滑動を防止した。

\section{$4 \cdot 3$ 奥只見ダム (コンクリート重力高さ157m) に おける不良岩処理}

奥只見の基礎岩艋は主として堅硬な斑レイ岩よりな るが，ダム天端標高付近の左右両端は天端標高から下 $50 \mathrm{~m}$ の範囲は不良岩盤であり, 特に右岸にはシルトス
トーンわよび蛇紋岩が広範囲に存在した。乙れらは乾 燥時はかなりの強度を有しているが，いったん水を含 めば軟弱化するものであって, 特別な処理を行なう必 要があった。 このため調查坑の掘削, ボーリング調査, 透水試験, グラウト試験, ベアリングテスト等を充分 に行なって, 不良岩艋部の地質調查を行なった結果, 下記の方針により基礎処理を行なった。

(1) 不良岩部は， $2 \mathrm{~m} \times 2 \mathrm{~m}$ の坑道切り取りを繰り返 して，Fig. 13 に示すようにげたばき式にコンクリー トで置き換えられ(置き換えコンクリート量 $15700 \mathrm{~m}^{3}$ ), コンタクトグラウトを行なってしゃ水効果をもたせる とともに，ダムからの力を下の堅硬な岩盤に伝える。

（2）ダム上流面ステップ，下流面ステップ等からカ

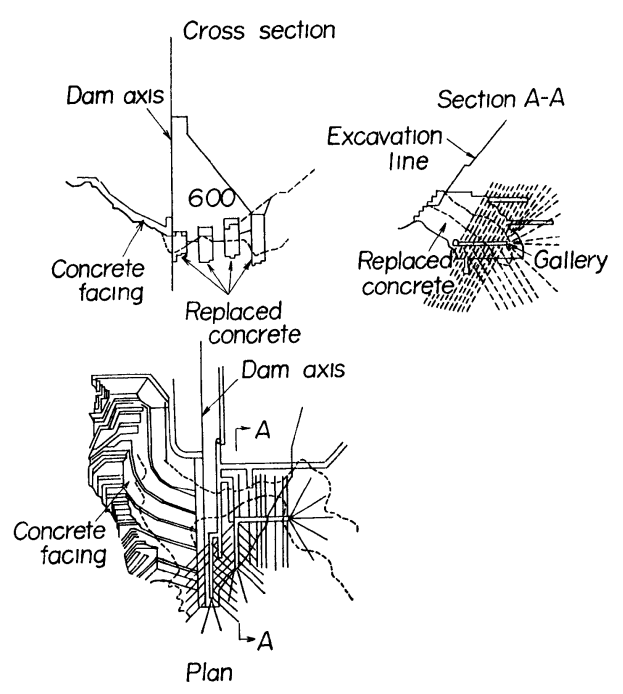

Fig. 13. Okutadami dam (Foundation treatment).

ーテングラウトを行ない，特に上流側は置き換えコン クリート内に設けた通廊からもさらにカーテングラウ 卜を行なって，置き換えコンクリート壁の中間に存在 する不良岩部を包むしゃ水幕を形成し，地山浸透水に よっててれらの岩が軟弱化するのを防止する。

（3）置き換えコンクリートおよびその中間の不良岩 部内に設けた通路から健岩に達するまで削孔し，コン ソリデーショングラウトを行ない中間の不良岩部を締 め固め，止水効果の向上および支持力の増大を図る。

（4）ダム前面（取水口前面）切り取り斜面の不良岩 部に厚さ $2 \mathrm{~m}$ の張コンクリートを設けるとともに，充 分コンソリデーショングラウトを行なって軟弱化を防 止する。

\footnotetext{
$4 \cdot 4$ 御衣ダム（傾斜土質しゃ水壁ロックフィル 高さ131m）における断層処理

ダムサイト付近の基盤は主として石英斑岩よりなっ ており，おおむね堅硬であるが，右岸の本流沿いに傾
} 
正

斜 $60 \sim 70^{\circ}$ の断首（福島断屏）が存在する. 断層は带 状の数条の粘土首を含む破砕帯となっており，その幅 は10〜30m程度であり，乙の部分には特別に止水処理

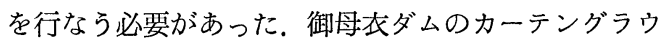
ト工は Fig. 14 に示すように, 土質しゃ水壁の基礎 部に設けられた 2 条のコンクリートカットオフから行 なわれたが，特に断層部においては前記の理由により 止水効果を上げるため次の方法が採られた。すすなわち，

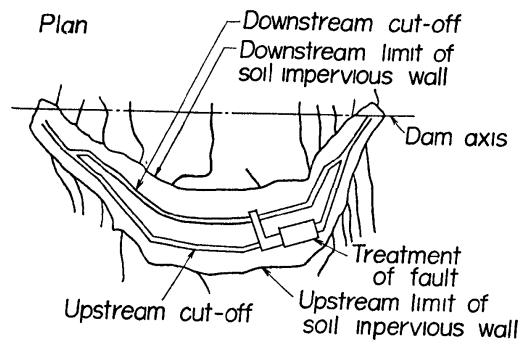

Curtain grouting
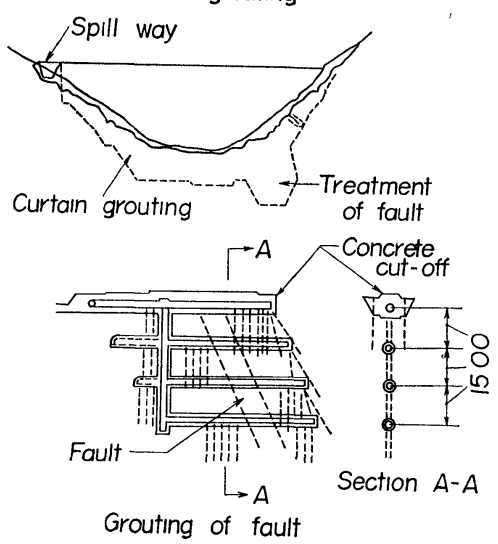

Fig. 14. Miboro dam (Foundation treatment).

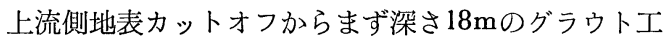

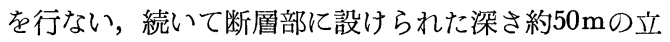
坑に連絡する 3 段の横坑から, 破碎帯とその周辺のぜ い弱部にグラウト工を行なう。横坑の間隔は $15 \mathrm{~m}$ とし， 横坑からのグラウト工は上段より順次行ない，削孔の 方向は鉛直, その長さは $18 \mathrm{~m}$ とし, 結果として断層部 を横切る幅約 $60 \mathrm{~m}$, 深さ約 $60 \mathrm{~m}$ のっ水幕を形成する. なお止水効果を上げるため鉛直方向のボーリンググラ ウトのほかに, 適宜横坑内から傘型のボーリンググラ ウトも行なう．下流側のカーテングラウト幕は地表の， カットオフからのグラウト工のみによって形成する。 以上の各種の基礎処理の後湛水が行なわれているが, すべて異常はなく所期の目的が達成されている。もち ろん各種の計測設備が埋設されており, 日常の状況が 詳しく観察されている。

5 最近の理論的, 実験的研究の二, 三の例

岩船の力学を基本的に追求するにあたって, 岩石そ
のものの非弾性的性質の問題, 節理の存在による応力 伝播や強度への影響の問題, 力学的性質の方向性の問 題等, 各種の複雑な事象が問題を非常に困難にしてい る. 乙れらの困難を解決するための種々の努力が行な われているが，最近の代表的な研究二，三を次にあげ てみる。

\section{5 - 1 不連続な節理性基盤の応力伝播と強度評価に ついての考察}

まず岩盤に節理系が発達しているときの表面載荷に よる応力の伝わり方や，不連続な節理系を含んだマス の強度を支配する二, 三の要因について串験と解析的 な考察を試みた林正夫の研究がある。現実の複雑をき わめる岩盤の力学的な挙動を論ずる第一歩として，と てでは簡易化された基本的なケースの積み上げを取り 扱っている.すすなお，一つの力学模型を考光，ひび 割れ面間の平均距離 $C$ の表面載荷幅 $T$ 亿対する比 $C / T$ を，ひび割れ規模と構造物規模の関連を付けるた めのパラメーターとして導入し，さらに，ひび割れ面 のせん断固有抵抗 $\tau_{r}$ の載荷圧 $q$ 亿対する比 $\tau_{r} / q$ や, ひび割れ面の摩擦係数 $\tan \varphi_{r}$ などの無次元パラメータ 一を考えに入れ，ひび割れ面の応力を局所的なすべり の各過程で弹性論によって近似的に求めて, ひび割れ 面の局所的なすべり条件を遂次的に検定しながら，局 所的なすべり領域を求める数值解法を試みている。 そ の結果として,

（1）載荷面近くのある深さ $D$ までは局所的なすべ りをひび割れ面上で生じながら鉛直応力は複合パスカ ル分布に従って下方に伝わっていき連続体としての弾 性計算に比べると載荷面の直下に応力分布かがたよる 傾向がある (Fig. 15, 16).

(2) 深さ $D$ より媣い所ではもはやひび割れ面での 局所的なすべり条件に触れないで，従来の連続体の力 学が適用できる。ただし，その領域付しては，Dを 仮想的な表面として，D面まで複合パスカル的に分布 してきた応力をての面の荷重とする， $D$ 面は転移面と 仮称し，その值は上述の諸パラメーターの関数として

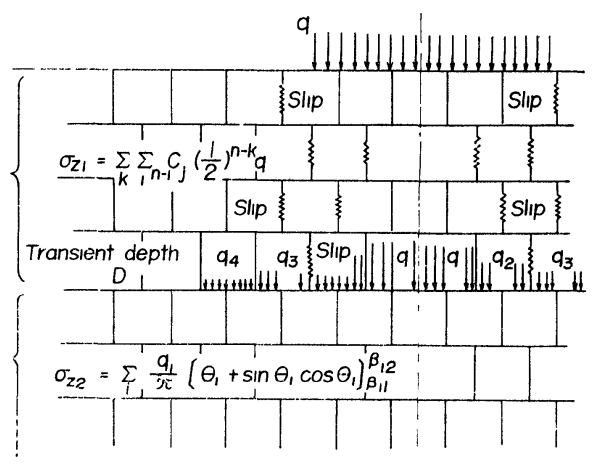

Fig. 15. Model of fissured foundation. 


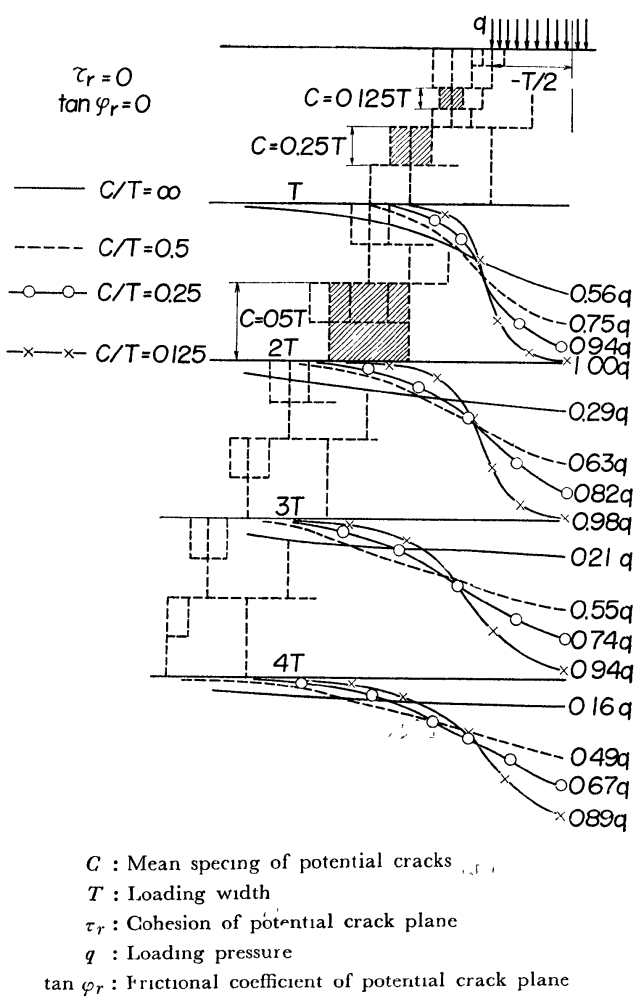

Fig. 16. Propagation of stress in the fissured foundation.

示される.

(3) このような傾向はモザイク状基盤を模擬して行 なった光弾性実験で確かめることができた。必ず山も よい合致は得られていないが，特性の理解に役だって いる，将来さらに考虑すべきは主節理の方向であり， 今後の研究に待たなければならない.

（4）不連続な節理面を含むぜい性実質部分の抵抗と， 節理部分の摩擦抵抗の和の形で初等力学的には巨視的 な強度を推定することになろうが，てれらの合成効果 は節理面の断続度や，隣接している同種の節理面の平 列度数，その近接の程度などのいろいろの要因によっ て影響を受けることを，室内実験で明らかにするとと ができた。乙れらの要因は上述の単純な合成抵抗值を 割り引きしなければならない傾向に影響を与える。

（5）室内実験はぜい性材料としてセッコウ，ケイソ ウ土，水の混合物を用い，不連続な節理面としてはマ イクロワックスを塗布した紙を挿入して模擬し，約 300 個の比較実験で上述の傾向を磼かめ，さらに皮膜 式光弾性実験で，各䬣理でとに主せん断ひずみのピー クが現われ，それらが互いに干渉する場合には上述の 強度の低下か起とることを明らかにした。

(6) 上述の不連続度数扔よび平列数のパラメーター に対して極值分布理論を導入してみたとてろ，単独節 昭和 40 年 6 月
理面の場合からの強度低下率についてかなり垁験と合 致した值を得ている.今後の研究の一つの方向を示し ているものと思われる. (Fig. 17).

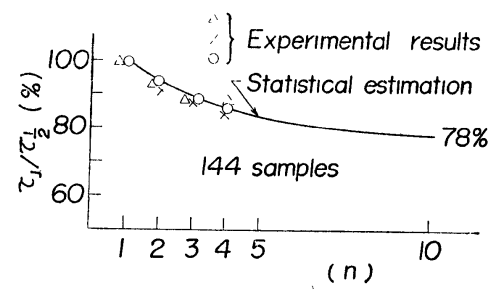

$\frac{\tau_{j}}{\tau_{\frac{1}{2}}}=1-\frac{\sigma_{0}}{\mu_{0}}(2 \log n)^{\frac{1}{2}}+\frac{\sigma_{0}}{u_{0}} \frac{\{\log (\log n)+\log 4 \pi\}}{2(2 \log n)^{\frac{1}{2}}}$

$n$ : Frequency of discontınuity

$\tau_{0}$ : Shearing strength of discontinuous joint

$\tau_{\frac{1}{2}}$ : Shearing strength of continuous joint

(Ratio of joint length to full shearing length is $\frac{1}{2}$ )

Fig. 17. Comparison of strength decrease between theory and experiment.

\section{$5 \cdot 2$ 岩盤の粘弾性的性質टその数学的表現の一例} 川淵桂により，岩盤の粘弾性モデルとして Fig. 18 が提案されている。乙れは岩盤表面の掘削過程におけ る岩盤内部の横坑の回りの応力弛緩のひずみ変化より 実測したもので，輝緑灰岩質の岩盤である，通常のジ ャッキによる変形試験に比へ，実ダムの載荷規模によ る変形を知りうる利点がある。ただしいまのところ除 荷の過程だけであり，載荷の過程は目下実測中である。 掘削経過と測定位置は Fig. 19 亿示すとおりである. Fig. 20 の AB, AC, BCの 3 区間ともによく適合する

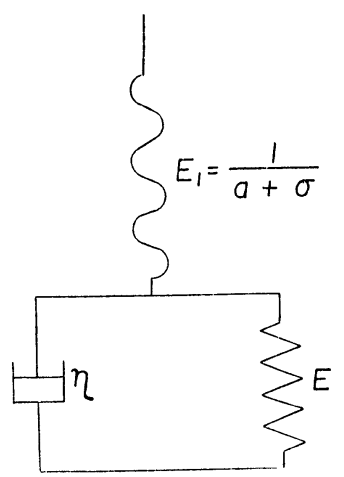

Fig. 18. Proposed nonlınear model.

モデルとして，非線型スプリングと Kelvin body を 直列に結んだ非線型モデルを提案しているわけである。 なおてのモデルの $\sigma=0$ での弾性係数は弾性波速度か ら求めた弾性係数とほぼ一致し，Kelvin model の Eはジャッキによる弾性係数值にほぼ等しい (Fig. 21)，ダムによる載荷のように載荷速度が遅いと， その弾性係数 $E_{0}$ は $1 / E_{0}=1 / E_{1}+1 / E$ となり， $\sigma=20$ $\mathrm{kg} / \mathrm{cm}^{2}$ とすれば $E_{0}=20000 \mathrm{~kg} / \mathrm{cm}^{2}$ となり,乙の值は ジャッキによる值の半分ほどとなる。 

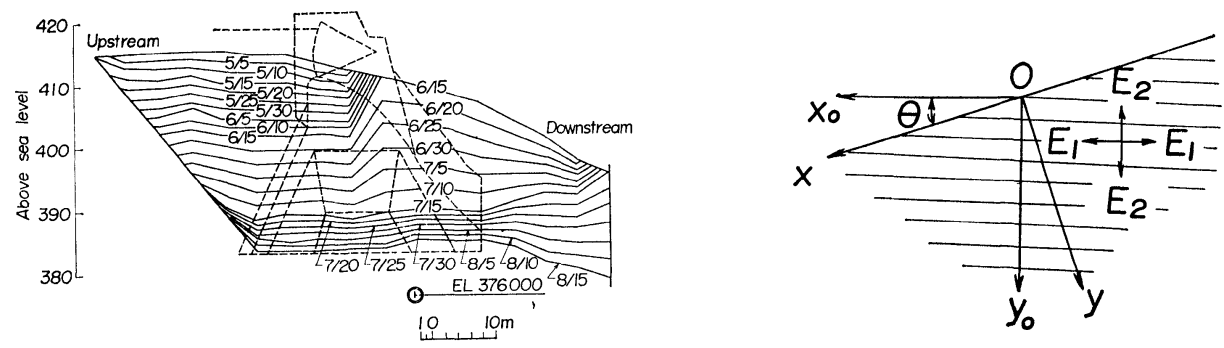

Fig. 19. Condition of excavation.

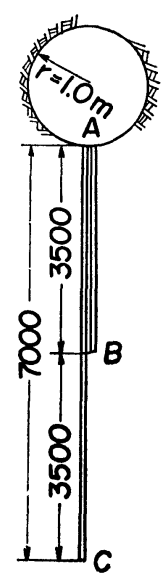

Fig. 20. Measure room and analysed section.

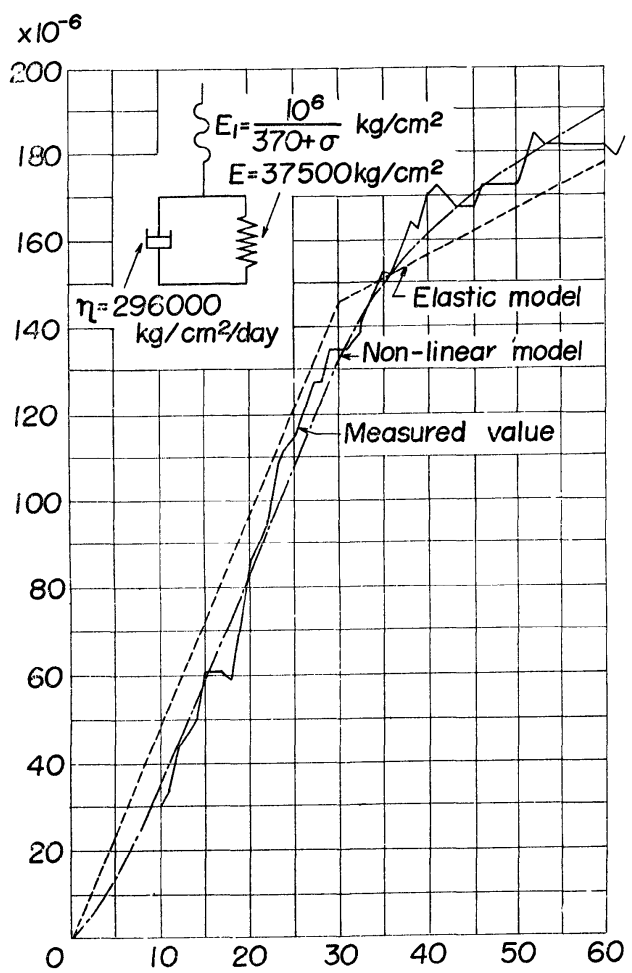

Fig. 21. Measured strain and calculated strain.

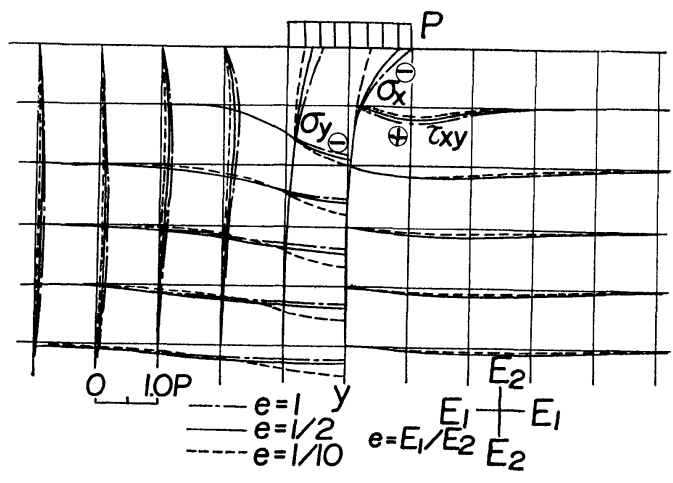

Stresses in $\left(\theta=0^{\circ}\right)$

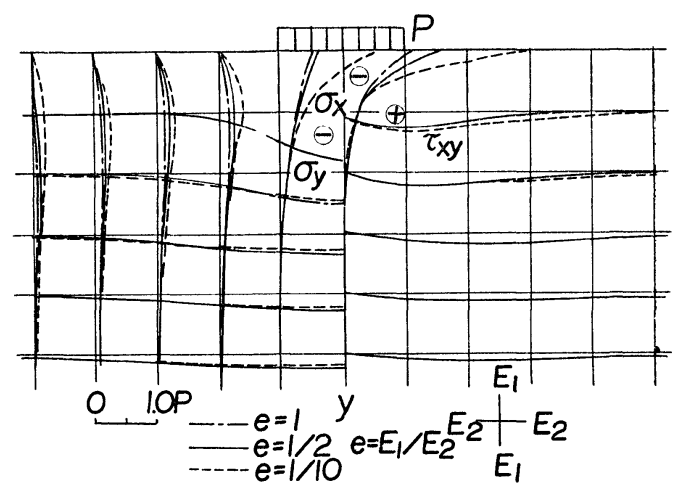

Stresses in $\left(\theta=90^{\circ}\right)$

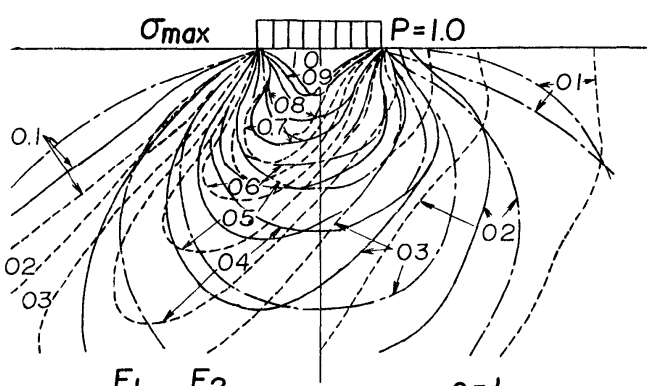

$$
\begin{aligned}
& E_{1} E_{2}-e=1 \\
& E_{e=E_{1} / E_{2}}-\cdots=1 / 2 \\
& E_{2} E_{1}=1 / 10 \\
& \text { Stresses in } \quad\left(\theta=45^{\circ}\right)
\end{aligned}
$$

Fig. 22. Stress distribution in the orthogonal anisotropic foundation. 


\section{5 -3 直交異方性基盤の応力状態の弾性解}

川本朓万は直交異方性の半無限基盤の表面にスラス ト，曲げ，およびせん断力の部分荷重が作用する場合 の応力解を求めている．その方法は応力関数の特性方 程式としての 4 階の変係数偏微分方程式（直交異方性 版の基濋式）を上記の境界条件に対し解いたものであ る. 数值計算例によると，いずれの荷重状態にわいて も大きいほうの弾性係数の方向の応力が異方性の影響 を受けやすく，等分布荷重の場合によると $\theta=0^{\circ}$ (鉛 直方向の主弹性係数が大）では荷重直下の鉛直応力 $\sigma_{y}$ は $e=1$ の等方等質の場合よりも増大し，かつての $\sigma_{y}$ の增加する範囲は深くなるほど広がる。一方, 水平応 力 $\sigma_{x}$ は異方性が大きいほど ( $e \rightarrow$ 小) 減少する. $\theta=90^{\circ}$

(水平方向の主弾性係数が大) では $\sigma_{y}$ は減少し $\sigma_{x}$ は 増大寸る. $\theta=45^{\circ}$ の場合の等最大直応力線図による と，大きいほうの主弾性係数の方向に伸びて分布する ことと係数比が大きいほど伸びが大きいととがわかる。

(Fig. 22).

\section{5 -4 基盤の安定性に関する模型実験方法の研究}

岩盤に各種分離面が存在して, その強度が支配され るととに着目した実験研究の一例として, 高野稳のも のがある，基盤の強度を総合的に示す支持力あるいは すべり抵抗を直接求めようとする場合，規模が大きく かつ複雑な場合には，たとえ大規模な現場実験によっ ても困難で, 実用上求めうる基盤の強度, すなわち卓 越した走行傾斜を持つ節理の発達した岩盤の圧縮強度, せん断強度, ならびに内部摩擦角, あるいはディス口 ケーション沿いのせん断強度ならびに基盤構造の幾何 学的形状とが, 基盤の総合的な強度を支配する要素で あるととをわれわれは知っているので，乙れらを測定 対象として安全率を求めうるスケールを得ようとする 立場をとっている。そして適確に把握しがたい実物を いくつか仮想的に分類し，標準基盤構造相似律を次元 解析的に定めて, 模型上に必要な機械的性質を上記各 相似要素に付与し, 模型実験的に耐荷力を各標準基盤 構造でとに求めて，それらの間に内插される安全度を 考究しょうとした。模型材料としてはプラスター，ヶ イソウ土, 砂, 水ガラス, ケイフッ化ソーダ, 重ソウ などを採用し，各分離面に付与すべき強度条件に特に 注意が払われた。またての実験は二次元的な安全性の みならず，三次元的なダムと基盤の複合構造としての 安定性の考究に努めたもので, 黒部第四ダムの基盤の 設計に資したものである。

\section{6 その他の問題}

以、トの颉明の内容はほとんどダムの基般の小学に関 連する問題に限定されている。しかし，ダム自体でも 㸵盤浸透流というきわ好困難で重要な問題が残され ており，また構造物を対象としたときには，トンネル
に関する岩盤力学というきわめて取り扱いの困難な問 題がある，以下ての問題に簡単に触れてみよう，岩盤 内の浸透流には, 流量, 水圧, 流線の形状, および流 速の各要素があるが，砂䍬のような多孔性物質内の浸 透流と異なり一般には不規則かつ複雑な分布をした割 れめ, 断層などの状態に影響されるため, 岩盤全体を 通じて画一的な法則（たとえば Darcy 法則のような） を単純に適用することには問題がある。しかし地質調 查の結果から判断して，岩盤が視的に見て等方均質 として取り扱光ると考光られる場合, 砂岩や頁岩また はそれらの互層のような異方性をもつ場合，また断層 破碎帯そのもののような場合には既知の理論を適用し て解析や実験を行なうとともある程度可能と考光られ る. 関西電力では二次元的割れめが縦横等間隔にある 場合を導線で表現し，また一方かんてんゲルで均質媒 質を作って岩盤基礎の浸透流圧力分布を比較したが， 両者がよく一致した結果を得たと発表している。また さらに割れめのある岩盤内の浸透流の模型試験法とし て各種の太さのパイプ系で置き換えて実験する方法, 解析的方法として割れめを通る部分と多孔質な岩塊内 を通る部分との 2 要素の組み合わせで基本方程式をた てる方法なども外国の研究者により提案されたてとも あり，しだいに一般の岩盤状態の場合にも適用可能な 方法が展開されていくことが希望される，黒四ダムに おいて大長昭雄によって研究された各種の岩盤透水問 題は，乙の地点に限られた前提にたつとはい光岩船浸 透流の問題に多くの前進をもたらした。

一方, トンネルに関する岩盤力学は, 工事施工法の 躍進的な発達に比へてて，やや停滞の域にあると残念な がらいわざるをえない面である。乙れはトンネル工事 に伴う自然条件のあまりに複雑なととに起因している ものかもしれない，トンネルに関連して地形地首との 関係, 断㬝の処理, 工法の選択, 巻厚の決定等, 問題 の解決は主として地質学にゆだねられる一方, 経験に まつとてろが大きかった。しかし長大トンネルまたは 海峡トンネル等の従来にない規模のものか計画施工さ れる今日では, 定性的な, あるいは経験のみによる判 定では満足できない面が出てくるととが考党られ，力 学的研究の必要性が要求されている。トンネルの力学 に関しては一般の岩盤力学に共通して岩の弾塑性的性 質, 破壊機構等が基本となるほか, 変質岩石の膨張力 が特に問題となる場合がある。 またトンネル工事に関 連しての理論研究としては, 土圧論, 弾性論, 塑性 墖による地压の研究が古典的な研究から今日に至る まで相当あるてとはよく知られているととである。 Forchheimer に始まり Heim, Schmidt らの理論, わ が国での山ロ゙, 岡本教授らの理論, 最近では村山教授 の免圧圈の弾塑性的解䣋などがあげられる。トンネル 


畑野正

工事に伴い涌水の問題も重要な点で, 最近では高橋彦 治の研究があげられる。直接工事に関連した問題で鋼 アーチ支保工の使用について, 坂本貞雄はその実物破 壊テストならびに実際の破壊実績に基づいて地山荷重 と支保工の耐力の関係を研究発表しているが，てのよ うな現場測定と力学との結合が重要な今後のいき方で あろう。

\section{7 結言}

全般的にいって, 取り扱い困難な岩盤力学の出発点 は，まず現物についての測定観察であり，てれを基礎 にしての理論の組み立てでなければならない，ての意 味で現場における測定法の開発を現状よりさらに大き く発展させるととが，岩盤力学を大きく発達させる第 一条件である,といえる，また今後の着実な発展のため には，限られた狭い視野の上にたつのではなく，ての 問題に関係のある各界相互間の連係と啓発が必要であ る.なお本紹介を草するにあたり, 土木学会岩盤力学 委員会の各分科会から資料を提出してもらったてとに 対し厚く謝意を表する次第である.
(昭和39年11月12日 岩の力学国内シンポジゥムにて講启)

参考 文 献

1）林正夫, 電力中央研究所技術報告（土木・63007） (1963).

2) 林正夫, 第 2 回岩盤力学シンポジウム前刷, 6 (1963).

3) 川淵桂, 土木学会第18回年次学術講演会前刷, p. 179 (1963).

4) 川本朓万, 発電水力, No.68, 1 (1964).

5) 高野稔，土木学会論文集，No.78，43 (1962).

6) 山口昇, 鉄道業研資料, 16, No. 11, 1 (1928).

7) 岡本舜三, 土木学会論文集, 昭和 $22 \cdot 23$ 年堌刊号, 60 (1949).

8）村山朔郎，“土と基礎の設計法”，p. 209 (1961) 土質工学会

9）高橋彦治, “涌水之地圧”, p. 1 (1963) 山海堂

10) 坂本貞雄, 第一トンネル工学シンポジウム, トン ネル工学シリーズ 1. p. 2 (1962) 